DEMOGRAPHIC RESEARCH

VOLUME 31, ARTICLE 42, PAGES 1275-1296

PUBLISHED 25 NOVEMBER 2014

http://www.demographic-research.org/Volumes/Vol31/42/

DOI: 10.4054/DemRes.2014.31.42

Research Article

Maternal longevity is associated with lower infant mortality

Graziella Caselli

Enrica Lapucci

Rosa Maria Lipsi

Lucia Pozzi

Giovannella Baggio
Ciriaco Carru

Luca Deiana

Claudio Franceschi

James W. Vaupel

(C) 2014 Caselli et al.

This open-access work is published under the terms of the Creative Commons Attribution NonCommercial License 2.0 Germany, which permits use, reproduction \& distribution in any medium for non-commercial purposes, provided the original author(s) and source are given credit.

See http://creativecommons.org/licenses/by-nc/2.0/de/ 


\section{Table of Contents}

1 Introduction 1276

2 Data and methods $\quad 1277$

$3 \quad$ Results 1281

$4 \quad$ Discussion and conclusion 1286

$5 \quad$ Acknowledgments $\quad 1289$

$\begin{array}{ll}\text { References } & 1290\end{array}$ 


\title{
Maternal longevity is associated with lower infant mortality
}

\author{
Graziella Caselli ${ }^{1}$ \\ Enrica Lapucci ${ }^{2}$ \\ Rosa Maria Lipsi ${ }^{3}$ \\ Lucia Pozzi ${ }^{4}$ \\ Giovannella Baggio 5
}

\author{
Ciriaco Carru ${ }^{6}$ \\ Luca Deiana ${ }^{7}$ \\ Claudio Franceschi ${ }^{8}$ \\ James W. Vaupel ${ }^{9}$
}

\begin{abstract}
OBJECTIVE

Referring to the multidisciplinary and multipurpose survey $\mathrm{AKeA} 2$, and focusing on family genealogy data on centenarian women and controls, this paper aims to verify the hypothesis that maternal longevity is associated with lower infant mortality in offspring, after having controlled for fertility characteristics, familial longevity and some contextual variables.
\end{abstract}

\section{METHODS}

The association between the longevity of a mother and her children's infant mortality level was assessed using a multivariate Poisson Regression Model with robust estimates, which is suitable for estimating consistently and efficiently the relative risk when binary data are used.

\footnotetext{
${ }^{1}$ Sapienza University of Rome, Italy.

${ }^{2}$ Sapienza University of Rome, Italy.

${ }^{3}$ Italian National Institute of Statistics (ISTAT), Italy. E-Mail: lipsi@istat.it.

${ }^{4}$ University of Sassari, Italy.

${ }^{5}$ City Hospital of Padua, Italy.

${ }^{6}$ University of Sassari, Italy.

${ }^{7}$ University of Sassari, Italy.

${ }^{8}$ University of Bologna, Italy.

${ }^{9}$ Max Planck Institute for Demographic Research, Germany.
} 


\section{RESULTS}

Our results show an association between longevity and infant mortality among the children of the Sardinians who survived to become centenarians. Infant mortality is significantly lower for children belonging to a mother born and living in Sassari and Oristano than Nuoro, close to each other and both located on the Western coast.

\section{Introduction}

In a previous descriptive analysis of data coming from the Sardinian AKeA $2^{10}$ survey, a lower number of deaths in the first year of life was observed among the children of women who survived to become centenarians (Lipsi et al. 2015). As was pointed out, for centenarian women, 79 per 1000 of offspring died in the first year of life (infant mortality rate). In contrast, among the offspring of the controls in the same cohorts as the centenarians who died in their 60 s or 70 s, the infant mortality rate was $118-172$ per 1000. Centenarian women also presented a lower infant mortality rate among their children than did women belonging to younger cohorts, particularly for those born between 1911 and 1916. A similar pattern was found for male counterparts (Lipsi et al. 2015). These results suggest a possible familial transmission of a lower mortality from parents to children, produced by shared genetic or socio-cultural factors (Perls, Albert, and Fretts 1997; Doblhammer 2000; Santoro et al. 2006; Raule et al. 2007; Rose et al. 2007, 2010; Invidia et al. 2010).

Sardinia has been characterized by the patriarchal structure of the family, by high and late fertility, and by the persisting tendency to postpone marriage and childbearing (Livi Bacci 1977; Zei, Lisa, and Astolfi 1990; Astolfi, Ulizzi, and Zonta 2002, Astolfi et al. 2009). Approximately until the First World War, Sardinia also had the lowest infant (and especially neonatal) mortality rates recorded in Italy, and stillbirth rates lower than the national average (Pozzi 2000; Gatti 2002) even though the maternal mean age at birth was particularly high (Caselli et al. 2006). After this period, Sardinia continued to have lower infant mortality rates, but not the lowest one.

For women, it is well known that childbearing and neonatal mortality are generally affected by the mother's age at birth or by the birth order of the child (Nault, Desjardins, and Legare 1990; Dollberg et al. 1996; Astolfi, Ulizzi, and Zonta 2002; Wunsch and Gourbin 2002; Joseph et al. 2005; Astolfi et al. 2009; Tentoni et al. 2012). Previous studies of Sardinian women of reproductive age showed that in the areas of central-eastern Sardinia with a high prevalence of centenarians, late maternity is

\footnotetext{
${ }^{10} \mathrm{AKeA} 2$ is the acronym of the survey of Sardinian Centenarians (see Lipsi et al. 2015).
} 
relatively common and perinatal and infant mortality is relatively low (Wagner 1950; Contini et al. 1989; Cavalli-Sforza et al. 1994). Furthermore, using data from the last decades of the 20th century, it was found that the maternal age of Sardinian women does not significantly affect neonatal and infant mortality (Astolfi et al. 2009; Tentoni et al. 2012). So far, to our knowledge, there has been no study of the relationship between a woman's longevity and infant mortality in her children.

Referring to the multidisciplinary and multipurpose survey AKeA2, and focusing on family genealogy data on centenarian women and controls, this paper aims to verify the hypothesis that maternal longevity is associated with lower infant mortality in offspring after having controlled for fertility characteristics, familial longevity and some contextual variables.

\section{Data and methods}

In the AKeA2 survey, 204 centenarians born between 1890 and 1904 (98 men and 106 women), in 126 municipalities throughout the island (out of the 377 Sardinian municipalities) were selected ${ }^{11}$. For the controls, 3 corresponding individuals for each centenarian born between 1905-1910, 1911-1916 and 1918-1925 (namely "Younger cohorts") and who were 80-95 years of age at the beginning of our study in 2004 - i.e., contemporaneous to centenarians - were selected (living controls). The survey also involved an additional 2 individuals for each centenarian from the same cohort (namely "Same cohorts as centenarians") who died in their late 60s (60-69 years) and late 70s (70-79 years) (dead controls).

In particular, for centenarian women and controls, the following variables, among the 20 available demographic characteristics, were collected: date of birth; date of death (if applicable); number and birth dates of their children; number of siblings and their birth order; and parents' date of birth and death.

Full information (100\%) is available for all individuals - centenarians and controls - regarding year and place of birth, date and place of death (if deceased), and sex and number of children. For all other demographic characteristics used in the analysis the completeness ranges from $84 \%$ to $95 \%$ (Lipsi et al. 2015).

For each sampled individual we also collected information on his or her educational level and occupation during active life. Unfortunately, it was not possible to include these variables in our analysis due to a great number of missing data and very low variability: as regards education, there is no information for $75.7 \%$ of subjects, and more than $20 \%$ were illiterate or had only 'some years of school'. As regards

\footnotetext{
${ }^{11}$ The description of the survey, the data collection details and some analysis of the data, have been presented in Lipsi et al. (2015).
} 
occupation, $87.7 \%$ of women were housewives and $81.0 \%$ of men were shepherds or farm-workers.

For our purpose, we considered vital information of all infants, listed by centenarians and controls, to determine their mortality status at 0-1 year. In AKeA2 survey, about $71.4 \%$ of the women $(\mathrm{N}=594)$ had at least one child, for a total of 2,228 infants. The association between infant mortality and maternal longevity was assessed using a multivariate Poisson Regression Model with robust estimates, which is suitable for estimating consistently and efficiently the relative risk when binary data are used (Zou 2004; Lee, Chuen, and Kee 2009). Thus, differences in infant mortality rate between the three cohorts of mothers were modeled by averaging the number of children who died at 0-1 year for the length of exposure (one year for each sampled woman's birth). As a result, the model allowed us to compare differences in the risk of dying at age 0-1 between children born to mothers who became centenarians with those born to the two other cohorts. Since information on age at death and/or age at birth, as well as maternal age at birth, which could be relevant "confounders," was not available for all children, a sensitivity analysis of the baseline model was carried out to evaluate the effects of misclassified death on the investigated association.

In particular, the baseline analysis (Scenario A) is based on 1,672 infants, which belong to families with the above-mentioned information available for all reported children. Thus, a total of 217 children were excluded due to missing information on their mortality status (total children=194) or on maternal age at birth (total alive children $=22$; total dead children=1) while an additional 339 children (total living children=298; total dead children $=41$ ) were not included in the baseline scenario because they were siblings of those who had been excluded (Table 1).

Since we also excluded children with available information on mortality status, a sensitivity analysis was performed on the 2228 total children, to take into account the complete distribution of living and dead children among mother cohorts. Moreover, the following two hypotheses were assumed for the 194 children with unknown mortality status. The first one assumes that all children with missing information are alive (Scenario B), while the second one assumes they are dead (Scenario C).

In each of the three analyses, we considered both unadjusted and adjusted risks (Incidence Rate Ratio: IRR). The remaining covariates were the year of birth of each child, his or her birth order, number of his or her siblings, mother and father's age at birth, and grandmother's age at death. In addition, we considered two contextual variables suggested by the literature to be influential: altitude and province of the mother's place of birth. (Caselli and Lipsi 2006; Breschi at al. 2007; Astolfi et al. 2009; Tentoni et al. 2012).

Statistical analyses were performed by means of STATA v. 11 procedures. 
Table 1: Distribution of children, alive or dead or unknown, according to the criteria of inclusion in the baseline scenario (Scenario A) by centenarian women and controls

\begin{tabular}{|c|c|c|c|c|}
\hline \multicolumn{5}{|c|}{ Children } \\
\hline Criteria of inclusion in baseline scenario $(A)$ & Alive & Dead & Unknown & Total \\
\hline \multicolumn{5}{|l|}{ Children of centenarians } \\
\hline Excluded & 18 & 1 & 79 & 98 \\
\hline Siblings of excluded children & 44 & 3 & 0 & 47 \\
\hline Included & 245 & 21 & 0 & 266 \\
\hline Total & 307 & 25 & 79 & 411 \\
\hline \multicolumn{5}{|l|}{ Children of same cohorts as centenarians } \\
\hline Excluded & 1 & 0 & 35 & 36 \\
\hline Siblings of excluded children & 104 & 20 & 0 & 124 \\
\hline Included & 437 & 73 & 0 & 510 \\
\hline Total & 542 & 93 & 35 & 670 \\
\hline \multicolumn{5}{|l|}{ Children of younger cohorts } \\
\hline Excluded & 3 & 0 & 80 & 83 \\
\hline Siblings of excluded children & 150 & 18 & 0 & 168 \\
\hline Included & 806 & 90 & 0 & 896 \\
\hline Total & 959 & 108 & 80 & 1147 \\
\hline \multicolumn{5}{|l|}{ Total children } \\
\hline Excluded & 22 & 1 & 194 & 217 \\
\hline Siblings of excluded children & 298 & 41 & 0 & 339 \\
\hline Included & 1488 & 184 & 0 & 1672 \\
\hline Total & 1808 & 226 & 194 & 2228 \\
\hline
\end{tabular}

\section{Results}

In the baseline analysis (Scenario A), the most important result concerned the significant lower infant mortality level among children of centenarian women compared to children of a mother of the same cohort as the centenarians, but who died between 60-79 years (Table 2).

According to the main literature (Nault, Desjardins, and Legare 1990; Dollberg et al. 1996; Joseph et al. 2005), infant mortality increases with the number of siblings, 
although the first child tends to exhibit a higher infant mortality than succeeding children. By contrast, maternal age at birth has no significant protective effect on infant mortality, as Astolfi et al. (2009) have pointed out in analyzing more recent Sardinian data. Meanwhile, a previous analysis of the association between longevity and fertility (Caselli et al. 2013) has found, in line with other studies, that in Sardinia, having the last child at advanced ages produced a protective effect on the mother's survival (Hamilton 1966; Charlesworth and Charlesworth 1980; Voland and Engel 1986; Snowdon et al. 1989; Kirkwood and Rose 1991; Perls, Albert, and Fretts 1997; Vaupel et al. 1998; Cooper and Sandler 1998; Müller et al. 2002; Yi and Vaupel 2004; McArdle et al. 2006). We could conclude that, referring to the AKeA2 study, late fertility has a significant positive effect on maternal survival but not on her children's mortality.

Infant mortality is significantly lower for children belonging to a mother born and living $^{12}$ in Sassari and Oristano than Nuoro, close to each other and both located on the Western coast.

\footnotetext{
${ }^{12}$ The rate of emigration for all sampled women was only $2 \%$.
} 
Table 2: Baseline scenario (Scenario A). Association between longevity and infant mortality: Results of the Multivariate Poisson Regression Model

\begin{tabular}{|c|c|c|c|c|c|c|}
\hline \multirow[b]{2}{*}{ Variables } & \multicolumn{2}{|c|}{$N\left(=1672\right.$ children $\left.^{\text {a }}\right)$} & \multirow[b]{2}{*}{$\begin{array}{l}\text { Unadjusted } \\
\text { IRR }\end{array}$} & \multirow[b]{2}{*}{$95 \% \mathrm{Cl}$} & \multirow[b]{2}{*}{$\begin{array}{l}\text { Adjusted } \\
\text { IRR }\end{array}$} & \multirow[b]{2}{*}{$95 \% \mathrm{Cl}$} \\
\hline & $\begin{array}{c}\text { Alive } \\
(\mathrm{N}=1488)\end{array}$ & $\begin{array}{c}\text { Dead } \\
(\mathrm{N}=184)\end{array}$ & & & & \\
\hline \multicolumn{7}{|l|}{ Cohorts } \\
\hline Centenarians (1890-1904) & 245 & 21 & 1.00 & & 1.00 & \\
\hline Same Cohorts as centenarians & 437 & 73 & $1.81^{* *}$ & $1.13-2.90$ & $1.78^{\star *}$ & $1.13-2.80$ \\
\hline $\begin{array}{l}\text { Younger Cohorts (1905-1910, } \\
\text { 1911-1916, 1918-1925) }\end{array}$ & 806 & 90 & 1.27 & $0.81-2.00$ & 1.27 & $0.73-2.23$ \\
\hline \multicolumn{7}{|l|}{ Year of birth } \\
\hline$\leq 1932$ & 384 & 54 & 1.00 & & 1.00 & \\
\hline 1933-1939 & 367 & 51 & 0.99 & $0.68-1.43$ & 1.28 & $0.83-1.97$ \\
\hline $1940-1946$ & 349 & 43 & 0.89 & $0.60-1.31$ & 1.15 & $0.66-2.00$ \\
\hline$\geq 1947$ & 388 & 36 & 0.69 & $0.45-1.04$ & 1.02 & $0.51-2.07$ \\
\hline \multicolumn{7}{|l|}{ Birth order } \\
\hline $1^{\text {st }}$ & 289 & 46 & 1.00 & & 1.00 & \\
\hline $2^{\text {nd }}-3^{\text {rd }}$ & 507 & 51 & $0.65^{* *}$ & $0.45-0.99$ & $0.60^{\star \star}$ & $0.42-0.87$ \\
\hline 4 th to 7 th & 570 & 68 & 0.78 & $0.55-1.09$ & $0.55^{\star *}$ & $0.35-0.85$ \\
\hline 8 th + & 122 & 19 & 0.98 & $0.60-1.59$ & $0.43^{* *}$ & $0.21-0.86$ \\
\hline \multicolumn{7}{|l|}{$N^{\circ}$ of siblings } \\
\hline Up to 3 & 369 & 32 & 1.00 & & 1.00 & \\
\hline $4-7$ & 789 & 84 & 1.20 & $0.82-1.76$ & 1.47 & $0.93-2.32$ \\
\hline $8+$ & 330 & 68 & $2.14^{\star \star *}$ & $1.43-3.19$ & $2.53^{\star * \star}$ & $1.52-4.21$ \\
\hline \multicolumn{7}{|l|}{ Mother's age at birth } \\
\hline Up to 29 years old & 630 & 84 & 1.17 & $0.87-1.56$ & 0.94 & $0.62-1.42$ \\
\hline $30-39$ & 687 & 77 & 1.00 & & 1.00 & \\
\hline $40+$ & 171 & 23 & 1.18 & $0.75-1.83$ & 1.47 & $0.86-2.50$ \\
\hline \multicolumn{7}{|l|}{ Father's age at birth } \\
\hline Up to 29 years old & 198 & 25 & 0.98 & $0.64-1.50$ & 0.86 & $0.56-1.31$ \\
\hline $30-39$ & 675 & 87 & 1.00 & & 1.00 & \\
\hline $40+$ & 610 & 72 & 0.92 & $0.69-1.24$ & 0.88 & $0.61-1.29$ \\
\hline Missing & 5 & 0 & - & & - & \\
\hline \multicolumn{7}{|l|}{ Grandmother's age at death } \\
\hline$<80$ years & 926 & 116 & 1.00 & & 1.00 & \\
\hline$\geq 80$ years & 504 & 62 & 0.98 & $0.73-1.32$ & 1.01 & $0.81-1.45$ \\
\hline Missing & 58 & 6 & 0.84 & $0.38-1.85$ & 1.18 & $0.52-2.66$ \\
\hline \multicolumn{7}{|l|}{ Altitude of mother's place of birth } \\
\hline Hill Coast & 296 & 34 & 1.00 & & 1.00 & \\
\hline Hill Inside & 555 & 82 & 1.24 & $0.96-1.82$ & 1.36 & $0.93-1.98$ \\
\hline Mountain Inside & 328 & 38 & 1.00 & $0.66-1.53$ & 0.84 & $0.53-1.31$ \\
\hline Plain & 309 & 30 & 0.85 & $0.53-1.37$ & 1.38 & $0.80-2.38$ \\
\hline Missing & & & & & & \\
\hline
\end{tabular}

\section{Table 2: (Continued)}


Caselli et al.: Maternal longevity is associated with lower infant mortality

\begin{tabular}{|c|c|c|c|c|c|c|}
\hline \multirow[b]{2}{*}{ Variables } & \multicolumn{2}{|c|}{$\mathrm{N}\left(=1672\right.$ children $\left.^{\mathrm{a}}\right)$} & \multirow{2}{*}{$\begin{array}{l}\text { Unadjusted } \\
\text { IRR }\end{array}$} & \multirow[b]{2}{*}{$95 \% \mathrm{Cl}$} & \multirow{2}{*}{$\begin{array}{l}\text { Adjusted } \\
\text { IRR }\end{array}$} & \multirow[b]{2}{*}{$95 \% \mathrm{Cl}$} \\
\hline & $\begin{array}{c}\text { Alive } \\
(\mathrm{N}=1488)\end{array}$ & $\begin{array}{c}\text { Dead } \\
(N=184)\end{array}$ & & & & \\
\hline \multicolumn{7}{|c|}{ Province of mother's place of birth } \\
\hline Nuoro & 577 & 54 & 1.00 & & 1.00 & \\
\hline Sassari & 613 & 102 & $0.60^{\star \star \star}$ & $0.44-0.82$ & $0.53^{\star \star \star}$ & $0.37-0.76$ \\
\hline Cagliari & 89 & 12 & 0.83 & $0.48-1.45$ & 0.88 & $0.48-1.62$ \\
\hline Oristano & 209 & 16 & $0.50^{\star *}$ & $0.29-0.84$ & $0.43^{\star *}$ & $0.23-0.80$ \\
\hline
\end{tabular}

a ) Coming from 335 mothers

*** $p$-value $<0.001 ;{ }^{* *} p$-value $<0.05$

The sensitivity analysis confirms the main baseline results (Tables 3 and 4), indicating the effects of the birth order and the number of siblings on infant mortality level. In particular, Scenario B shows a significant increase in infant mortality starting from the fourth brother or sister. Nevertheless, some peculiarities highlighted by the results of the two models refer to the unadjusted IRR. Particularly in Scenario B, the infant mortality level of centenarians' children is also lower than that of the younger cohorts' children, while in Scenario C, in which we assume that the 194 children without information are dead, the infant mortality level of younger cohorts' children is significantly lower than that of centenarians. Of course this result is due, at least in part, to the higher number of infant deaths included in the last scenario, which especially involves the children of centenarian women. 
Table 3: Scenario B. Association between longevity and infant mortality: Results of the Multivariate Poisson Regression Model

\begin{tabular}{|c|c|c|c|c|c|c|}
\hline \multirow[b]{2}{*}{ Variables } & \multicolumn{2}{|c|}{$\mathrm{N}\left(=2228\right.$ children $\left.^{\mathrm{a}}\right)$} & \multirow[b]{2}{*}{$\begin{array}{l}\text { Unadjusted } \\
\text { IRR }\end{array}$} & \multirow[b]{2}{*}{$95 \% \mathrm{Cl}$} & \multirow[b]{2}{*}{$\begin{array}{l}\text { Adjusted } \\
\text { IRR }\end{array}$} & \multirow[b]{2}{*}{$95 \% \mathrm{Cl}$} \\
\hline & $\begin{array}{l}\text { Not Dead } \\
(\mathrm{N}=2002)\end{array}$ & $\begin{array}{c}\text { Dead } \\
(\mathrm{N}=226)\end{array}$ & & & & \\
\hline \multicolumn{7}{|l|}{ Cohorts } \\
\hline Centenarians (1890-1904) & 386 & 25 & 1.00 & & 1.00 & \\
\hline Same cohorts as centenarians & 577 & 93 & $2.28^{\star \star \star}$ & $1.47-3.55$ & $1.68^{\star *}$ & $1.06-2.66$ \\
\hline $\begin{array}{l}\text { Younger cohorts } \\
(1905-1910,1911-1916,1918-1925)\end{array}$ & 1039 & 108 & $1.55^{\star \star}$ & $1.00-2.39$ & 1.18 & $0.69-2.02$ \\
\hline \multicolumn{7}{|l|}{ Year of birth } \\
\hline$\leq 1932$ & 496 & 65 & 1.00 & & 1.00 & \\
\hline 1933-1939 & 472 & 61 & 0.99 & $0.70-1.39$ & 1.24 & $0.79-1.93$ \\
\hline $1940-1946$ & 450 & 57 & 0.97 & $0.68-1.38$ & 1.25 & $0.72-2.14$ \\
\hline$\geq 1947$ & 584 & 43 & $0.59^{* \star}$ & $0.40-0.88$ & 1.00 & $0.50-2.00$ \\
\hline \multicolumn{7}{|l|}{ Birth order } \\
\hline $1^{\text {st }}$ & 345 & 54 & 1.00 & & 1.00 & \\
\hline $2 n d-3^{\text {rd }}$ & 620 & 58 & $0.63^{* *}$ & $0.44-0.91$ & $0.58^{\star *}$ & $0.40-0.85$ \\
\hline 4th to 7 th & 716 & 83 & 0.77 & $0.54-1.05$ & $0.56^{\star \star}$ & $0.35-0.93$ \\
\hline 8 th + & 170 & 29 & 1.08 & $0.69-1.67$ & 0.57 & $0.28-1.14$ \\
\hline Missing & 151 & 2 & $0.10^{* *}$ & $0.02-0.40$ & 0.39 & $0.09-1.68$ \\
\hline \multicolumn{7}{|l|}{$N^{\circ}$ of siblings } \\
\hline Up to 3 & 448 & 34 & 1.00 & & 1.00 & \\
\hline $4-7$ & 1012 & 102 & 1.30 & $0.90-1.88$ & $1.57^{\star \star}$ & $1.01-2.43$ \\
\hline $8+$ & 542 & 90 & $2.02^{\star \star \star}$ & $1.38-2.95$ & $2.25^{\star \star}$ & $1.37-3.71$ \\
\hline \multicolumn{7}{|l|}{ Mother's age at birth } \\
\hline Up to 29 years old & 788 & 99 & 1.12 & $0.86-1.48$ & 0.96 & $0.63-1.47$ \\
\hline $30-39$ & 896 & 99 & 1.00 & & 1.00 & \\
\hline $40+$ & 227 & 28 & 1.10 & $0.72-1.68$ & 1.23 & $0.75-2.02$ \\
\hline Missing & 91 & 0 & - & & - & \\
\hline \multicolumn{7}{|l|}{ Father's age at birth } \\
\hline Up to 29 years old & 255 & 32 & 1.02 & $0.69-1.49$ & 0.89 & $0.60-1.31$ \\
\hline $30-39$ & 857 & 105 & 1.00 & & 1.00 & \\
\hline $40+$ & 774 & 89 & 0.94 & $0.72-1.24$ & - & \\
\hline Missing & 116 & 0 & - & & & \\
\hline \multicolumn{7}{|l|}{ Grandmother's age at death } \\
\hline$<80$ years & 1225 & 142 & 1.00 & & 1.00 & \\
\hline$\geq 80$ years & 657 & 77 & 1.01 & $0.77-1.32$ & 1.11 & $0.85-1.45$ \\
\hline Missing & 120 & 7 & 0.53 & $0.23-1.19$ & 1.29 & $0.60-2.76$ \\
\hline \multicolumn{7}{|l|}{ Altitude of mother's place of birth } \\
\hline Hill coast & 418 & 43 & 1.00 & & 1.00 & \\
\hline Hill inside & 732 & 92 & 1.20 & $0.84-1.70$ & 1.35 & $0.95-1.90$ \\
\hline Mountain inside & 413 & 47 & 1.10 & $0.74-1.61$ & 0.91 & $0.60-1.36$ \\
\hline Plain & 432 & 44 & 0.99 & $0.66-1.47$ & 1.53 & $0.97-2.41$ \\
\hline Missing & 7 & 0 & - & & - & \\
\hline \multicolumn{7}{|l|}{ Province of mother's place of birth } \\
\hline Nuoro & 747 & 67 & 1.00 & & 1.00 & \\
\hline Sassari & 782 & 115 & $0.64^{\star *}$ & $0.48-0.86$ & $0.57^{\star \star}$ & $0.40-0.80$ \\
\hline Cagliari & 145 & 19 & 0.90 & $0.55-1.48$ & 0.89 & $0.53-1.48$ \\
\hline Oristano & 329 & 25 & $0.55^{\star \star}$ & $0.36-0.83$ & $0.41^{\star \star}$ & $0.25-0.68$ \\
\hline
\end{tabular}

${ }^{\text {a) Coming from } 424 \text { mothers }}$

p-value $<0.001 ;{ }^{\star *}$ p-value $<0.05$ 
Caselli et al.: Maternal longevity is associated with lower infant mortality

Table 4: Scenario C. Association between longevity and infant mortality: Results of the Multivariate Poisson Regression Model

\begin{tabular}{|c|c|c|c|c|c|c|}
\hline \multirow[b]{2}{*}{ Variables } & \multicolumn{2}{|c|}{$\mathrm{N}\left(=2228\right.$ children $\left.^{\mathrm{a}}\right)$} & \multirow[b]{2}{*}{$\begin{array}{l}\text { Unadjusted } \\
\text { IRR }\end{array}$} & \multirow[b]{2}{*}{$95 \% \mathrm{Cl}$} & \multirow[b]{2}{*}{$\begin{array}{l}\text { Adjusted } \\
\text { IRR }\end{array}$} & \multirow[b]{2}{*}{$95 \% \mathrm{Cl}$} \\
\hline & $\begin{array}{l}\text { Not Dead } \\
(\mathrm{N}=1808)\end{array}$ & $\begin{array}{c}\text { Dead } \\
(\mathrm{N}=420)\end{array}$ & & & & \\
\hline \multicolumn{7}{|l|}{ Cohorts } \\
\hline Centenarians (1890-1904) & 307 & 104 & 1.00 & & 1.00 & \\
\hline Same cohorts as centenarians & 542 & 128 & 0.75 & $0.53-1.07$ & $1.54^{\star *}$ & $1.13-2.01$ \\
\hline $\begin{array}{l}\text { Younger cohorts } \\
(1905-1910,1911-1916,1918-1925)\end{array}$ & 959 & 188 & $0.65^{\star \star}$ & $0.46-0.91$ & 1.19 & $0.91-1.56$ \\
\hline \multicolumn{7}{|l|}{ Year of birth } \\
\hline$\leq 1932$ & 464 & 97 & 1.00 & & 1.00 & \\
\hline 1933-1939 & 443 & 90 & 0.98 & $0.75-1.28$ & 1.09 & $0.79-1.48$ \\
\hline 1940-1946 & 429 & 78 & 0.89 & $0.67-1.18$ & 1.03 & $0.66-1.52$ \\
\hline$\geq 1947$ & 472 & 155 & $1.43^{\star \star}$ & $1.05-1.94$ & 1.06 & $0.68-1.63$ \\
\hline \multicolumn{7}{|l|}{ Birth order } \\
\hline $1^{\text {st }}$ & 324 & 75 & 1.00 & & 1.00 & \\
\hline $2 n d-3^{\text {rd }}$ & 582 & 96 & 0.75 & $0.56-1.03$ & $0.73^{\star *}$ & $0.55-0.97$ \\
\hline 4th to 7 th & 678 & 121 & 0.81 & $0.62-1.04$ & $0.68^{\star *}$ & $0.49-0.97$ \\
\hline 8 th + & 158 & 41 & 1.10 & $0.78-1.53$ & 0.75 & $0.46-1.21$ \\
\hline Missing & 66 & 87 & $3.02^{\star \star \star}$ & $2.18-4.19$ & 0.55 & $0.26-1.14$ \\
\hline \multicolumn{7}{|l|}{$N^{\circ}$ of siblings } \\
\hline Up to 3 & 407 & 75 & 1.00 & & 1.00 & \\
\hline $4-7$ & 921 & 193 & 1.11 & $0.84-1.48$ & 1.24 & $0.93-1.65$ \\
\hline $8+$ & 480 & 152 & $1.55^{\star \star}$ & $1.14-2.09$ & 1.74 & $1.28-2.35$ \\
\hline \multicolumn{7}{|l|}{ Mother's age at birth } \\
\hline Up to 29 years old & 744 & 143 & 1.01 & $0.82-1.25$ & 0.84 & $0.63-1.14$ \\
\hline $30-39$ & 836 & 159 & 1.00 & & 1.00 & \\
\hline $40+$ & 215 & 40 & 0.98 & $0.70-1.37$ & 1.00 & $0.68-1.46$ \\
\hline Missing & 13 & 78 & $5.36^{\star \star \star}$ & $4.33-6.64$ & $2.76^{\star \star}$ & $1.13-6.73$ \\
\hline \multicolumn{7}{|l|}{ Father's age at birth } \\
\hline Up to 29 years old & 236 & 51 & 1.16 & $0.87-1.56$ & 1.10 & $0.81-1.51$ \\
\hline $30-39$ & 815 & 147 & 1.00 & & 1.00 & \\
\hline $40+$ & 726 & 137 & 1.04 & $0.83-1.29$ & 0.95 & $0.73-1.24$ \\
\hline Missing & 31 & 85 & $4.79^{\star \star \star}$ & $3.75-6.13$ & $2.89^{\star *}$ & $1.25-6.70$ \\
\hline \multicolumn{7}{|l|}{ Grandmother's age at death } \\
\hline$<80$ years & 1113 & 254 & 1.00 & & 1.00 & \\
\hline$\geq 80$ years & 614 & 120 & 0.88 & $0.70-1.11$ & 1.08 & $0.89-1.32$ \\
\hline Missing & 81 & 46 & $1.95^{\star *}$ & $1.27-2.98$ & 1.07 & $0.75-1.56$ \\
\hline \multicolumn{7}{|l|}{ Altitude of mother's place of birth } \\
\hline Hill coast & 365 & 96 & 1.00 & & 1.00 & \\
\hline Hill inside & 652 & 172 & 1.00 & $0.75-1.34$ & 0.95 & $0.73-1.25$ \\
\hline Mountain inside & 396 & 64 & $0.67^{\star \star}$ & $0.49-0.92$ & $0.68^{\star \star}$ & $0.49-0.95$ \\
\hline Plain & 392 & 84 & 0.85 & $0.60-1.19$ & 0.93 & $0.68-1.25$ \\
\hline Missing & 3 & 4 & 2.74 & $1.39-5.39$ & 4.89 & 2.16-11.07 \\
\hline \multicolumn{7}{|l|}{ Province of mother's place of birth } \\
\hline Nuoro & 684 & 129 & 1.00 & & 1.00 & \\
\hline Sassari & 719 & 178 & 0.80 & $0.61-1.04$ & $0.72^{\star \star}$ & $0.56-0.94$ \\
\hline Cagliari & 125 & 39 & 1.19 & $0.73-1.94$ & 0.90 & $0.64-1.28$ \\
\hline Oristano & 280 & 74 & 1.05 & $0.75-1.47$ & 0.86 & $0.65-1.13$ \\
\hline
\end{tabular}

a) Coming from 424 mothers

*** $p$-value $<0.001 ;{ }^{* *} p$-value $<0.05$ 


\section{Discussion and conclusion}

Our research question asked if maternal longevity was associated with lower infant mortality in offspring. Controlling for fertility characteristics, age of mother at death, and other contextual variables, our study seems to confirm the results of previous descriptive analyses, showing a significant lower infant mortality among the children of the Sardinians who survived to become centenarians. Specifically, we found a significantly higher risk of infant mortality among children born to those women belonging to the same cohorts as the centenarians, but who died before reaching 80 years old. The fact that significant differences in infant mortality are found only for these oldest cohorts could provide an important support for our result. In particular, by comparing the same cohorts, we can conjecture that the differences observed do not depend on different quality in the data for infant deaths, and in particular on a different attitude to registering a birth following an infant's immediate death. The criterion of "legal viability" had been in force in Italy from the end of the 19th century until 1970. Newborn babies were regarded as living if they gave signs of viability up to the moment of being registered (to be done within 5 days of birth). Those who died before being registered were to be regarded as stillborn babies from a legal point of view and, consequently, their birth record as well as their death record do not exist. While the oldest cohorts (the centenarians) may well have been less sensitive to the question of registering the birth and death of their children than the younger cohorts (living controls) leading to a possible underestimation of the infant mortality of their children, it is unlikely that these underestimations discriminated between individuals who became centenarians and those of the same cohort who died before reaching 80 years.

Moreover, even it was not possible to account for some relevant socio-economic and/or genetic factors, our result could raise many questions about the potential determinants affecting the lower infant mortality of the children born to our centenarian women.

Is it possible that the genes favoring an individual's longevity may also transmit robustness to their progeny? And again, can territorial characteristics that favor the longevity of individuals also have a positive impact on their children surviving infancy?

Since we are not able to control for individual genetic factors, we have controlled for the longevity of the grandmother too. Unfortunately, our results did not find a significant association between infant mortality and the grandmother's age at death.

In order to evaluate possible protective genetic factors stemming from the territorial level, Astolfi et al. (2009) estimated, for the period 1850-1969, the consanguinity level by the percentage of consanguineous marriages and the average inbreeding coefficients in Sardinia (Moroni et al. 1972, Cavalli-Sforza et al. 2004). Both estimates presented higher values in internal/mountainous areas, where the 
presence of centenarians was higher (Poulain et al. 2004). They suggested an association between the propensity to marry within the same familial group and the aptitude for late and successful maternity. Other Sardinian genetic traits may explain the underlying association, such as the abnormal frequencies of the $\mathrm{Y}$ chromosome and mtDNA (Cavalli-Sforza et al. 1994; Zei et al. 2003; Carru et al. 2003; Pes et al. 2004; Astolfi et al. 2009) or some mutations of the genetic makeup partially determined by endemic malaria in the past (Modiano et al. 1986; Caglia et al. 1997). The AkeA researchers found that the gene pool in the Sardinians of the particularly remote mountainous region is relatively small (Carru et al. 2003; Pes et al. 2004). For example, the local people have small red blood cells, which is thought to protect them against malaria and help prevent blood clots (Kosoy et al. 2011). Our results from Scenario C showed that infant mortality in Sardinia is lower in the mountainous areas where a large part of our centenarians mainly come from.

Other explanations could be proposed. Might the socio-economic and cultural factors that are behind the longevity of centenarians be partly the same as those protecting their offspring? Theoretically, a woman who protects her own health and survival by her behavior will also protect the health of her offspring, both directly (as she is in a better state of health at the time of childbearing) and indirectly (as she is more careful of her children's health). Practically, Sardinian centenarian women and their controls are an exceptionally homogenous group in terms of occupational and educational status: they were housewives whose education was either non-existent or went no further than primary school. The socio-occupational status of their husbands is unknown, but the men in the oldest cohorts living in internal areas were usually either peasants or shepherds, following an age-old tradition handed down from parent to child. In view of the role that socio-occupational and educational factors play in infant mortality studies, these are not discriminatory factors in our study of Sardinian centenarians.

Probably, the women's eating habits and familial conditions are represented by other factors not identified in our survey, e.g. just as being or not being the owner of a flock could be a discriminating condition between rich and poor individuals.

In order to better distinguish genetic from contextual determinants, it would be important to measure the evolution of the risk of death at specific stages during the first year of life, distinguishing in particular the early neonatal mortality rates (dying in the first month of life) which are more influenced by genetic factors as well as by maternal health. In our sample, we observed a similar proportion of early deaths $(43 \%$ of children died in the first month of life) and post neonatal deaths ( $47 \%$ of children died from two months to 1 year) partially due to the above-mentioned under-registration of births and deaths in the first week of life. Thus, in considering the low number of total deaths, we 
were, unfortunately, unable to make a distinct analysis of each infant mortality component.

However, as longevity, reproductive behavior and infant mortality, broadly speaking, are the outcome of various factors of a genetic or external nature, our results suggest, as do Astolfi et al. (2009), that Sardinia might be a candidate for in-depth studies on the association of longevity and reproductive longevity, including the positive infant survival (lower infant mortality) of the offspring of long-lived women.

\section{Acknowledgments}

The authors wish to thank Iris Levitis for her assistance with English language editing. Moreover we are grateful to two anonymous reviewers and the Associate Editor for their helpful comments and suggestions.

The AKeA2 demographic survey of Sardinian Centenarians, directed by W. James Vaupel, Max Planck Institute for Demographic Research, Rostock, Germany (financed by the U.S. National Institute on Aging (NIA), subcontract with Duke University n.03SC-NIH-1027). 


\section{References}

Astolfi, P., Caselli, G., Fiorani, O., Lipsi, R.M., Lisa, A., and Tentoni, S. (2009). Late reproduction behaviour in Sardinia: spatial analysis suggests local aptitude towards reproductive longevity. Evolution and Human Behaviour 30(2): 93-102. doi:10.1016/j.evolhum behav.2008.09.001.

Astolfi, P., Ulizzi, L., and Zonta, L. (2002). Trends in childbearing and stillbirth risk: heterogeneity among Italian regions. Human Biology 74(2): 185-196. doi:10.1353/hub.2002.0015.

Breschi, M., Mazzoni, S., Melis, P.M., and Pozzi, L. (2007). Nuove indagini per l'analisi della mortalità nei primi anni di vita in Sardegna. In: Breschi, M. and Pozzi, L. (eds.), Salute, malattia e sopravvivenza in Italia fra '800 e '900. Udine: Forum: 195-220. doi:10.1400/119204.

Caglia, A., Novelletto, A., Dobosz, M., Malaspina, M., Ciminelli, B.M., and Pascali, V.L. (1997). Y chromosome STR loci in Sardinia and continental Italy reveal islander-specific haplotypes. Eur. J. Hum. Genet. 5(5): 288-292.

Carru, C., Pes, G.M., Deiana, L., Baggio, G., Franceschi, C., Lio, D., Balistreri, C.R., Candore, G., Colonna-Romano, G., and Caruso, C. (2003). Association between the HFE mutations and longevity: a study in Sardinian population. Mechanisms of Ageing and Development 124(4): 529-532. doi:10.1016/S0047-6374(030) 00032-0.

Caselli, G. and Lipsi, R.M. (2006). Survival differences among the oldest old in Sardinia: who, what, where, and why? Demographic Research 14(13): 267-294. doi:10.4054/DemRes.2006.14.13.

Caselli, G., Lipsi, R.M., Lapucci, E., and Vaupel, J.W. (2013). Exploring Sardinian Longevity: Women Fertility and Parental Transmission of Longevity. Vienna Yearbook of Population Research XX: 1-18. doi:10.1553/populationyearbook.

Caselli, G., Pozzi, L., Vaupel, J.W., Deiana, L., Pes, G., Carru, C., Franceschi, C., and Baggio, G. (2006). Family clustering in Sardinian longevity: A genealogical approach. Experimental Gerontology 41(8): 727-736. doi:10.1016/j.exger.2006.05.009.

Cavalli-Sforza, L.L., Menozzi, P., and Piazza, A. (1994). The history and geography of human genes. Princeton, NJ: Princeton University. 
Cavalli-Sforza, L.L., Moroni, A., and Zei, G. (2004). Consanguinity, inbreeding, and genetic drift in Italy. In Levin, S.A. and Horn, H.S. (eds.). Monographs in Population Biology. Princeton: Princeton University Press.

Charlesworth, D. and Charlesworth, B. (1980). Sex differences in fitness and selection for centric fusions between sex-chromosomes and autosomes. Genetical Research 35(2): 205-214. doi:10.1017/ S0016672300014051.

Contini, M., Cappello, N., Griffo, R., Rendine, S., and Piazza, A. (1989). Géolinguistique et géogénétique, une démarche interdisciplinaire. Géolinguistique 4: 129-197.

Cooper, G.S. and Sandler, D.P. (1998). Age at Natural Menopause and Mortality. Annals of Epidemiology 8(4): 229-235. doi:10.1016/ S1047-2797(97)00207-X.

Doblhammer, G. (2000). Reproductive history and mortality later in life: a comparative study: England and Wales and Austria. Population Studies 54(2): 169-176. doi:10.1080/713779087.

Dollberg, S., Seidman, D.S., Armon, Y., Stevenson, D.K., and Gale, R. (1996). Adverse perinatal outcome in the older primiparae. J Perinatol. 16: 93-97.

Gatti, A.M. (2002). La mortalità infantile tra Ottocento e Novecento. La Sardegna nel panorama italiano. Università degli Studi di Cagliari Editore, Cagliari, Italia: Quaderni del dipartimento di Ricerche Economiche e Sociali, Sezione statistica.

Hamilton, W.D. (1966). The moulding of senescence by natural selection. Journal of Theoretical Biology 12(1): 12-45. doi:10.1016/0022-5193(66)90184-6.

Invidia, L., Salvioli, S., Altilia, S., Pierini, M., Panourgia, M.P., Monti, D., De Rango, F., Passarino, G., and Franceschi C. (2010). The frequency of Klotho KL-VS polymorphism in a large Italian population, from young subjects to centenarians, suggests the presence of specific time windows for its effect. Biogerontology 11(1): 67-73. doi:10.1007/s10522-009-9229-z.

Joseph, K.S., Allen, A.C., Dodds, L., Turner, L.A., Scott, H., and Liston, R. (2005). The perinatal effects of delayed childbearing. Obstetrics \& Gynecology 105(6): $1410-1418$.

doi:10.1097/01.AOG.0000 163256.83313.36.

Kirkwood, T.B.L. and Rose, M.R. (1991). Evolution of senescence: late survival sacrificed for reproduction. Philosophical Transactions of the Royal Society of 
Caselli et al.: Maternal longevity is associated with lower infant mortality

London. Series B: Biological Sciences. 332(1262): 15-24. doi:10.1098/rstb.1991.0028.

Kosoy, R., Ransom, M., Chen, H., Marconi, M., Macciardi, F., Glorioso, N., Gregersen, P.K., Cusi, D., and Seldin, M.F. (2011). Evidence for malaria selection of a CR1 haplotype in Sardinia. Genes and immunity 12(7): 582-588. doi:10.1038/gene.2011.33.

Lipsi, R.M., Caselli, G., Pozzi, L., Baggio, G.; Carru, C., Franceschi, C., Vaupel, J.W., and Deiana, L. (2015). Demographic Characteristics of Sardinian Centenarian Genealogies: Preliminary Results of the AKeA2 Study. Under review.

Livi Bacci, M. (1977). A history of Italian fertility during the last two centuries. Princeton: Princeton University Press.

Lee, J., Chuen S.T., and Kee S.C. (2009). A practical guide for multivariate analysis of dichotomous outcomes. Ann Acad Med Singapore 38(8): 714-719.

McArdle, P.F., Pollin, T.I., O'Connell, J.R., Sorkin, J.D., Agarwala, R., Schäffer, A.A., Streeten, E.A., King, T.M., Shuldiner, A.R., and Mitchell, B.D. (2006). Does having children extend life span? A genealogical study of parity and longevity in the Amish. The Journals of Gerontology Series A: Biological Sciences and Medical Sciences 61(2): 190-195. doi:10.1093/gerona/61.2.190.

Modiano, G., Terrenato, L., Scozzari, R., Santachiara-Benerecetti, S.A., Ulizzi, L., Santolamazza, C., Petrucci, R., and Santolamazza, P. (1986). Population genetics in Sardinia (with a historical account of the birth of the Haldane "malaria hypothesis"). Roma: Accademia nazionale dei Lincei: 257-330.

Moroni, A., Anelli, A., Anghinetti, W., Lucchetti, L., Rossi, O., and Siri, E. (1972). La consanguineità umana nell'isola di Sardegna dal secolo XVIII al secolo XX. L'Ateneo parmense. Acta Naturalia 8(1): 69-92.

Müller, H-G., Chiou, J-M., Carey, J.R., and Wang, J.L. (2002). Fertility and life span: late children enhance female longevity. Journal of Gerontology: Biological Science 57A(5): 202-206.

Nault, F., Desjardins, B., and Legare, J. (1990). Effects of reproductive behavior on infant mortality of French-Canadians during the seventeenth and eighteenth centuries. Population Studies 44(2): 273-285. doi:10.1080/0032472031000144596.

Perls, T., Albert, L., and Fretts, R.C. (1997). Middle-age mothers live longer. Nature 389(6647): 133. doi:10.1038/38148. 
Pes, G.M., Lio, D., Carru, C., Deiana, L., Baggio, G., Franceschi, C., Ferrucci, L, Oliveti, F., Scola, L., Crivello, A., Candore, G., Colonna-Romano, G., and Caruso, C. (2004). Association between longevity and cytokine gene polymorphisms. A study in Sardinian centenarians. Aging Clinical and Experimental Research 16(3): 244-248. doi:10.1007/BF03327391.

Poulain, M., Pes, G.M., Grasland, C., Carru, C., Ferrucci, L., Baggio, G., Franceschi, C., and Deiana, L. (2004). Identification of a geographic area characterized by extreme longevity in the Sardinia island: the AKeA study. Experimental Gerontology 39(9): 1423-1429. doi:10.1016/j.exger.2004.06.016.

Pozzi, L. (2000), La lotta per la vita. Evoluzione e geografia della sopravvivenza in Italia fra' 800 e'900. Udine: Forum.

Raule, N., Sevini, F., Santoro, A., Altilia, S., and Franceschi, C. (2007). Association studies on human mitochondrial DNA: methodological aspects and results in the most common age-related diseases. Mitochondrion 7(1-2): 29-38. doi:10.1016/j.mito.2006.11.013.

Rose, G., Passarino, G., Scornaienchi, V., Romeo, G., Dato, S., Bellizzi, D., Mari, V., Feraco, E., Maletta, R., Bruni, A., Franceschi, C., and De Benedictis, G. (2007). The mitochondrial DNA control region shows genetically correlated levels of heteroplasmy in leukocytes of centenarians and their offspring. BMC Genomics 8(1): 293. doi:10.1186/1471-2164-8-293.

Rose, G., Romeo, G., Dato, S., Crocco, P., Bruni, AC., Hervonen, A., Majamaa, K., Sevini, F., Franceschi, C., and Passarino, G. (2010). Genetics of Healthy Ageing Project Consortium. Somatic point mutations in mtDNA control region are influenced by genetic background and associated with healthy aging: a GEHA study. PLoS One 5(10): e13395. doi:10.1371/journal.pone.0013395.

Santoro, A., Salvioli, S., Raule, N., Capri, M, Sevini, F., Valensin, S., Monti, D., Bellizzi, D., Passarino, G., Rose, G., De Benedictis, G., and Franceschi, C. (2006). Mitochondrial DNA involvement in human longevity. Biochimica et Biophysica Acta (BBA) - Bioenergetics 1757(9-10): 1388-1399. doi:10.1016/j.bbabio.2006. 05.040 . 
Snowdon, D.A., Kane, R.L., Beeson, W.L., Burke, G.L., Sprafka, J.M., Potter, J., Iso, H., Jacobs, R., and Phillips, R.L. (1989). Is early natural menopause a biological marker of health and aging? American Journal of Public Health 79(6): 709-714. doi:10.2105/

AJPH.79.6.709.

Tentoni, S., Lisa, A., Fiorani, O., Lipsi R.M., Caselli, G., and Astolfi, P. (2012). Spatial Analysis of the aptitude to late maternity on the Island of Sardinia. Journal of Biosocial Sciences 44(3): 257-272. doi:10.1017/S0021932011000575.

Vaupel, J.W., Carey, J.R., Christensen, K., Johnson, T.E., Yashin, A.I., Holm, N.V., Iachine, I.A., Kannisto, V., Khazaeli, A.A., Liedo, P., Longo, V., Zeng, Y., Manton, K.G., and Curtsinger, J.W. (1998). Biodemographic Trajectories of Longevity. Science 280(5365): 855-860. doi:10.1126/science.280.5365.855.

Voland, E. and Engel, C. (1986). Ist das postmenopausale Sterbealter Variable einer fitness-maximierenden Reproduktionsstrategie? Anthropologischer Anzeiger 44(1):19-34.

Wagner, M.L. (1950). La lingua Sarda. Storia spirito e forma. Berna. Francke.

Wunsch, G. and Gourbin, C. (2002). Parent's age at birth of their offspring and child survival. Biodemography and Social Biology 49(3-4): 174-184. doi:10.1080/19485565.2002.9989057

Yi, Z. and Vaupel, J.W. (2004). Association of Late Childbearing With Healthy Longevity among The Oldest-Old in China. Population Studies 58(1): 37-53. doi:10.1080/0032472032000175437.

Zei, G., Lisa, A., and Astolfi, P. (1990). Fertility and malaria in Sardinia. Annals of Human Biology 17(4): 315-330. doi:10.1080/0301446 9000001092. 
Zei, G., Lisa, A., Fiorani, O., Magri, C., Quintana-Murci, L., Semino, O., and SantachiaraBenerecetti, A. S. (2003). From surnames to the history of Y chromosomes: The Sardinian population as a paradigm. European Journal Human Genetics 11(10): 802-807. doi:10.1038/ sj.ejhg.5201040.

Zou, G. (2004). A Modified Poisson Regression Approach to Prospective Studies with Binary Data. American Journal of Epidemiology. 159(7): 702-706. doi:10.1093/aje/kwh090. 
Poulain, M., Pes, G.M., Grasland, C., Carru, C., Ferrucci, L., Baggio, G., Franceschi, C., and Deiana, L. (2004). Identification of a geographic area characterized by extreme longevity in the Sardinia island: the AKeA study. Experimental Gerontology 39(9): 14231429. doi:10.1016/j.exger.2004.06.016.

Pozzi, L. (2000). La lotta per la vita. Evoluzione e geografia della sopravvivenza in Italia fra' 800 e'900. Udine: Forum.

Raule, N., Sevini, F., Santoro, A., Altilia, S., and Franceschi, C. (2007). Association studies on human mitochondrial DNA: methodological aspects and results in the most common age-related diseases. Mitochondrion 7(1-2): 29-38. doi:10.1016/j.mito.2006.11.013.

Rose, G., Passarino, G., Scornaienchi, V., Romeo, G., Dato, S., Bellizzi, D., Mari, V., Feraco, E., Maletta, R., Bruni, A., Franceschi, C., and De Benedictis, G. (2007). The mitochondrial DNA control region shows genetically correlated levels of heteroplasmy in leukocytes of centenarians and their offspring. BMC Genomics 8(1): 293. doi:10.1186/1471-2164-8-293.

Rose, G., Romeo, G., Dato, S., Crocco, P., Bruni, AC., Hervonen, A., Majamaa, K., Sevini, F., Franceschi, C., and Passarino, G. (2010). Genetics of Healthy Ageing Project Consortium. Somatic point mutations in mtDNA control region are influenced by genetic background and associated with healthy aging: a GEHA study. PLoS One 5(10): e13395. doi:10.1371/journal.pone.0013395.

Santoro, A., Salvioli, S., Raule, N., Capri, M, Sevini, F., Valensin, S., Monti, D., Bellizzi, D., Passarino, G., Rose, G., De Benedictis, G., and Franceschi, C. (2006). Mitochondrial DNA involvement in human longevity. Biochimica et Biophysica Acta (BBA) Bioenergetics 1757(9-10): 1388-1399. doi:10.1016/j.bbabio.2006. 05.040 . 
Snowdon, D.A., Kane, R.L., Beeson, W.L., Burke, G.L., Sprafka, J.M., Potter, J., Iso, H., Jacobs, R., and Phillips, R.L. (1989). Is early natural menopause a biological marker of health and aging? American Journal of Public Health 79(6): 709-714. doi:10.2105/ AJPH.79.6.709.

Tentoni, S., Lisa, A., Fiorani, O., Lipsi R.M., Caselli, G., and Astolfi, P. (2012). Spatial Analysis of the aptitude to late maternity on the Island of Sardinia. Journal of Biosocial Sciences 44(3): 257-272. doi:10.1017/S0021932011000575.

Vaupel, J.W., Carey, J.R., Christensen, K., Johnson, T.E., Yashin, A.I., Holm, N.V., Iachine, I.A., Kannisto, V., Khazaeli, A.A., Liedo, P., Longo, V., Zeng, Y., Manton, K.G., and Curtsinger, J.W. (1998). Biodemographic Trajectories of Longevity. Science 280(5365): 855-860. doi:10.1126/science.280.5365.855.

Voland, E. and Engel, C. (1986). Ist das postmenopausale Sterbealter Variable einer fitness-maximierenden Reproduktionsstrategie? Anthropologischer Anzeiger 44(1):19-34.

Wagner, M.L. (1950). La lingua Sarda. Storia spirito e forma. Berna. Francke.

Wunsch, G. and Gourbin, C. (2002). Parent's age at birth of their offspring and child survival. Biodemography and Social Biology 49(3-4): 174-184. doi:10.1080/19485565.2002.9989057

Yi, Z. and Vaupel, J.W. (2004). Association of Late Childbearing With Healthy Longevity among The Oldest-Old in China. Population Studies 58(1): 37-53. doi:10.1080/0032472032000175437.

Zei, G., Lisa, A., and Astolfi, P. (1990). Fertility and malaria in Sardinia. Annals of Human Biology 17(4): 315-330. doi:10.1080/0301446 9000001092. 
Zei, G., Lisa, A., Fiorani, O., Magri, C., Quintana-Murci, L., Semino, O., and Santachiara-Benerecetti, A. S. (2003). From surnames to the history of Y chromosomes: The Sardinian population as a paradigm. European Journal Human Genetics 11(10): 802-807. doi:10.1038/ sj.ejhg. 5201040.

Zou, G. (2004). A Modified Poisson Regression Approach to Prospective Studies with Binary Data. American Journal of Epidemiology. 159(7): 702-706. doi:10.1093/aje/kwh090. 